\title{
Trifluoromethyl ethers - synthesis and properties of an unusual substituent
}

\author{
Frédéric R. Leroux ${ }^{* 1}$, Baptiste Manteau ${ }^{1}$, Jean-Pierre Vors ${ }^{2}$ \\ and Sergiy Pazenok ${ }^{3}$
}

Open Access

\author{
Review \\ Address: \\ ${ }^{1}$ Laboratoire de Stéréochimie, Université Louis Pasteur (ECPM), \\ CNRS, 25 rue Becquerel, F - 67087 Strasbourg Cedex 2, France, \\ ${ }^{2}$ Bayer CropScience SA, Centre de Recherches de La Dargoire, \\ 14-20 Rue Pierre Baizet, F - 69009 Lyon, France and ${ }^{3}$ Bayer \\ CropScience AG, Alfred-Nobel-Strasse 50, D - 40789 Monheim, \\ Germany \\ Email: \\ Frédéric R. Leroux* - frederic.leroux@ecpm.u-strasbg.fr \\ * Corresponding author
}

Beilstein Journal of Organic Chemistry 2008, 4, No. 13. doi:10.3762/bjoc. 4.13

Received: 08 January 2007

Accepted: 22 April 2008

Published: 29 April 2008

(C) 2008 Leroux et al; licensee Beilstein-Institut.

License and terms: see end of document.

\begin{abstract}
After nitrogen, fluorine is probably the next most favorite hetero-atom for incorporation into small molecules in life scienceoriented research. This review focuses on a particular fluorinated substituent, the trifluoromethoxy group, which is finding increased utility as a substituent in bioactives, but it is still perhaps the least well understood fluorine substituent in currency. The present review will give an overview of the synthesis, properties and reactivity of this important substituent.
\end{abstract}

\section{Introduction}

Nowadays, fluorine containing compounds are synthesized in pharmaceutical research on a routine basis and about $10 \%$ of all marketed pharmaceuticals contain a fluorine atom. There has been an enormous increase in the use of fluorine containing compounds for medicinal applications. For example, nine of the 31 new chemical entities approved in 2002 contain one or several fluorine atoms. According to the World Drug Index (WDI), there are 128 fluorinated compounds with US trade names. Even more fluorinated drugs are predicted to be developed in the near future, as fluoro-organic compounds continue to attract attention in the field of chemistry and biochemistry [1].
Fluorine as a substituent in active ingredients plays a significant and increasingly important role. Currently about $15 \%$ of the pesticides listed in the 13th edition of the Pesticide Manual contain at least one fluorine atom. The biggest group of fluorinated pesticides are the compounds containing a trifluoromethyl group (mainly at aromatic rings), followed by aromatic compounds containing an isolated fluorine atom (one and more). However, according to the 12th and 13th edition of the pesticide manual only five pesticides containing $\mathrm{OCF}_{3}$-groups are so far registered (see Figure 1). The proinsecticide Indoxacarb acting as a voltage-gated sodium channel (vgSCh) modulator, the insect growth regulant (IGR) Triflumuron, the plant 
<smiles>CCOc1ccc(NC(=O)N2CCOC3(C(=O)OC)Cc4cc(Cl)ccc4C3=N2)cc1</smiles>

Indoxacarb<smiles>Cc1nc(C(F)(F)F)c(C(=O)Nc2c(Br)cc(OC(F)(F)F)cc2Br)s1</smiles>

Thifluzamide<smiles>CC(C)C(O)(c1ccc(OC(F)(F)F)cc1)c1ccncn1</smiles>

Triflumuron<smiles>COc1ccccc1S(=O)(=O)N(C(=O)O)n1nc(OC)n(C)c1=O</smiles>

Flucarbazone-sodium

Figure 1: $\mathrm{OCF}_{3}$-bearing pesticides.

growth regulator Flurprimidol, the inhibitor of the respiratory chain and succinate dehydrogenase (SD) Thifluzamide as well as the inhibitor of acetolactate synthase (ALS) Flucarbazonesodium. It was estimated that the number of fluorinated compounds currently under development represent some $35-50 \%$ of the all active ingredients under development [2]

One or several fluorine atoms as substituents at specific sites in an organic compound can dramatically alter its chemical and biological nature. In fact, the incorporation of fluorine into a bioactive compound allows a simultaneous change in the electronic, lipophilic and steric parameters, all of which can influence both the pharmacodynamic and pharmacokinetic properties of the candidate [3].

What is so particular about fluorine? Due to its comparable size, the fluorine atom $(1.47 \AA)$ can mimic a hydrogen atom (1.20 $\AA$ ) or a hydroxy group $(1.40 \AA)$ in a bioactive compound with respect to steric requirements at receptor sites. Its high electronegativity (4.0 according to the Pauling scale) can have a pronounced influence on the reactivity pattern of a molecule. The most common reason for incorporating fluorine into a molecule is to reduce the rate of oxidative metabolism. However, the increased oxidative stability of fluorinated molecules has nothing to do with the greater strength of the carbon-fluorine bond relative to the carbon-hydrogen bond. In fact, biological oxidation does not involve the homolysis of $\mathrm{C}-\mathrm{H}$ or $\mathrm{C}-\mathrm{F}$ bonds. More relevant are the bond energies and heats of formation of $\mathrm{H}-\mathrm{O}$ and $\mathrm{C}-\mathrm{O}$ bonds relative to those of $\mathrm{F}-\mathrm{O}$ bonds. As the latter are unfavorable all alternative mechan- isms avoiding attack at fluorine always apply in biological systems [4].

Moreover, the presence of fluorine atoms in biologically active molecules can enhance their lipophilicity and thus their in vivo uptake and transport. In particular, the trifluoromethyl group $\left(-\mathrm{CF}_{3}\right)$ confers increased stability and lipophilicity in addition to its high electronegativity [5-9]. However, another fluorinated substituent, the trifluoromethoxy group, is becoming more and more important in both agrochemical research and pharmaceutical chemistry [10,11].

The trifluoromethoxy group is perhaps the least well understood fluorine substituent. When asked to draw up a list of textbook substituents, hardly anyone would consider associating such an "exotic entity" like trifluoromethoxy to the lasting popularity of the carboxyl, acetyl, formyl, nitro, amino, hydroxyl and sulfo groups. Nevertheless, the occurrence of $\mathrm{OCF}_{3}$-substituted organics, the majority of which are aromatic compounds, has significantly increased in the recent years [12].

In the 1950s and 1960s the successful development of $\alpha$-fluorinated ethers as volatile, non-toxic, non-explosive and fast-acting inhalation anesthetics was quickly followed by applications of anti-inflammatory agents. Investigations of the anesthetic properties of $\alpha$-fluorinated ethers were undertaken on the rational basis that replacement of the hydrogen atom in already known "anesthetic molecules" by fluorine should result in derivatives having improved thermal stabilities relative to the inhalation anesthetics in common use at that time (cyclopropane and 


\begin{tabular}{|c|c|c|c|c|}
\hline Entry & a-Fluorinated ethers & b.p. $\left[{ }^{\circ} \mathrm{C}\right]$ & Common names & Brand names \\
\hline 1 & $\mathrm{~F}_{2} \mathrm{HC}-\mathrm{O}-\mathrm{CHFCF}_{3}$ & $12.4 \pm 25.0$ & Desflurane & Suprane® \\
\hline 2 & $\mathrm{~F}_{2} \mathrm{HC}-\mathrm{O}-\mathrm{CHClCF}_{3}$ & $48.5 \pm 0.0$ & Isoflurane & Forane $®$ \\
\hline 3 & $\mathrm{FH}_{2} \mathrm{C}-\mathrm{O}-\mathrm{CH}\left(\mathrm{CF}_{3}\right)_{2}$ & $49.5 \pm 25.0$ & Sevoflurane & Sevofrane $®$ \\
\hline 4 & $\mathrm{~F}_{2} \mathrm{HC}-\mathrm{O}-\mathrm{CF}_{2}-\mathrm{CHFCl}$ & $59.9 \pm 25.0$ & Enflurane & Ethrane® \\
\hline 5 & $\mathrm{~F}_{2} \mathrm{HC}-\mathrm{O}-\mathrm{CHF}-\mathrm{CF}_{2}-\mathrm{CHF}_{2}$ & $60.9 \pm 25.0$ & $\mathrm{BAX} 3224$ & Synthane $®$ \\
\hline 6 & $\mathrm{H}_{3} \mathrm{C}-\mathrm{O}-\mathrm{CF}_{2}-\mathrm{CHFBr}$ & $87.0 \pm 25.0$ & Roflurane & DA 893 \\
\hline 7 & $\mathrm{H}_{3} \mathrm{C}-\mathrm{O}-\mathrm{CF}_{2}-\mathrm{CHCl}_{2}$ & $105.0 \pm 0.0$ & Methoxyflurane & Pentrane® \\
\hline
\end{tabular}

ether), like the halo ether anesthetic Fluoroxene (Fluoromar ${ }^{\circledR}$, $\mathrm{F}_{3} \mathrm{C}-\mathrm{H}_{2} \mathrm{C}-\mathrm{O}-\mathrm{CH}=\mathrm{CH}_{2}$ ). Numerous analogues [13] were prepared and evaluated (Table 1). Meanwhile, cyclic analogues bearing the fluorinated 1,3-dioxolanes moiety [14] have largely replaced Fluoroxene in its clinical use. Many anesthetics currently used are powerful positive allosteric modulators of $\mathrm{GABA}_{\mathrm{A}}[15]$.

Numerous new $\mathrm{OCF}_{3}$ containing compounds have been prepared, clinically evaluated and in many cases marketed as drugs with enhanced effectiveness, often coupled with diminished side-effects [10]. Between 2004 and 2007 the number of structures bearing an $\mathrm{OCF}_{3}$-substituent has more than doubled (from 30,000 to 74,514). They are documented in 18,000 literature references (SciFinder Scholar), most being patent applications $(\sim 11,000)$, but also in close to 7000 research articles. In contrast, trifluoromethoxy substituted heterocycles are relatively rare, although numerous structures are protected by patent applications.

\section{Review}

\section{Preparation of Trifluoromethyl Ethers Nucleophilic substitution}

The first aryl trifluoromethylethers were prepared by L. Yagupol'skii in 1955 starting from substituted anisoles [16]. The displacement of chlorine by fluorine was realized with anhydrous hydrogen fluoride or with antimony trifluoride in the presence of antimony pentachloride (Scheme 1 and Table 2) [16-19].

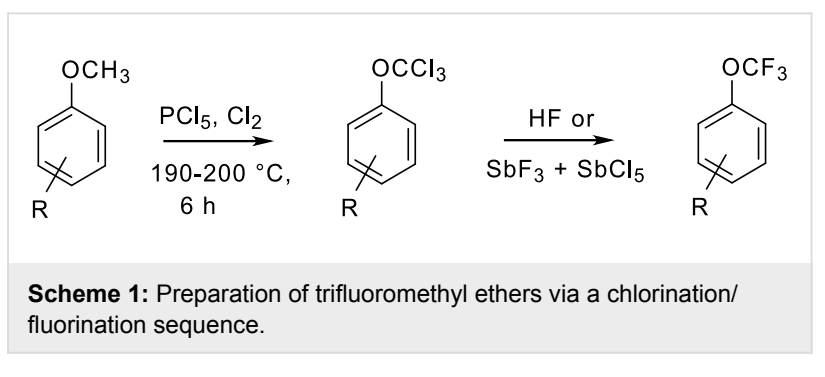

The photochlorination which works well with electron-deficient anisoles cannot be applied to anisole itself. In fact, halogen attack on the phenyl ring proceeds more easily than radical chlorination of the methyl group. Louw and Franken could show that with elemental chlorine, photostimulated in refluxing tetrachloromethane, essentially trichloromethylanisole is obtained [20]. The fluorination of the trichloromethyl ether succeeds then easily as shown above. The chlorination/ fluorination sequence described above can be simplified by producing the trichloromethyl aryl ethers without isolation and through in situ conversion into the final trifluoromethyl aryl ethers. As Feiring could show more recently, the phenol is heated together with tetrachloromethane, anhydrous hydrogen fluoride and catalytic amounts of boron trifluoride in a closed pressure vessel under autogeneous pressure up to $150{ }^{\circ} \mathrm{C}$ [21]. However, substrates containing ortho substituents capable of hydrogen bonding to the hydroxy group are not suitable starting materials. The stoechiometric use of tetrachloromethane lowers the yield and milder conditions afford essentially chlorodifluoromethoxy derivatives (Scheme 2 and Table 3).

Table 2: Synthesis of $\mathrm{ArOCF}_{3}$ compounds starting from substituted anisoles.

\begin{tabular}{lllll} 
Anisole & ArOCCl & Yield (\%) & ArOCF & Yield (\%) \\
\hline $4-\mathrm{ClC}_{6} \mathrm{H}_{4} \mathrm{OMe}$ & $4-\mathrm{ClC}_{6} \mathrm{H}_{4} \mathrm{OCCl}_{3}$ & 77 & $4-\mathrm{ClC}_{6} \mathrm{H}_{4} \mathrm{OCF}_{3}$ & \\
$2-\mathrm{ClC}_{6} \mathrm{H}_{4} \mathrm{OMe}$ & $2-\mathrm{ClC}_{6} \mathrm{H}_{4} \mathrm{OCCl}_{3}$ & 69 & $2-\mathrm{ClC}_{6} \mathrm{H}_{4} \mathrm{OCF}_{3}$ & 40 \\
$4-\mathrm{FC}_{6} \mathrm{H}_{4} \mathrm{OMe}$ & $4-\mathrm{FC}_{6} \mathrm{H}_{4} \mathrm{OCCl}_{3}$ & 66 & $4-\mathrm{FC}_{6} \mathrm{H}_{4} \mathrm{OCF}_{3}$ & \\
$2,4-\mathrm{Cl}_{2} \mathrm{C}_{6} \mathrm{H}_{3} \mathrm{OMe}$ & $2,4-\mathrm{Cl}_{2} \mathrm{C}_{6} \mathrm{H}_{3} \mathrm{OCCl}_{3}$ & 70 & $2,4-\mathrm{Cl}_{2} \mathrm{C}_{6} \mathrm{H}_{3} \mathrm{OCF}_{3}$ & 20 \\
$4-\mathrm{NCC}{ }_{6} \mathrm{H}_{4} \mathrm{OMe}$ & $4-\mathrm{NCC}_{6} \mathrm{H}_{4} \mathrm{OCCl}_{3}$ & 50 & $4-\mathrm{NCC}_{6} \mathrm{H}_{4} \mathrm{OCF}_{3}$ & 20 \\
$4-\mathrm{Cl}(\mathrm{O}) \mathrm{CC}_{6} \mathrm{H}_{4} \mathrm{OMe}$ & $4-\mathrm{Cl}(\mathrm{O}) \mathrm{CC}_{6} \mathrm{H}_{4} \mathrm{OCCl}_{3}$ & 83 & $4-\mathrm{F}(\mathrm{O}) \mathrm{CC}_{6} \mathrm{H}_{4} \mathrm{OCF}_{3}$
\end{tabular}


Yarovenko and Vasil'eva developed an approach based on the readily accessible, although highly toxic aryl chlorothionoformates $\mathbf{1}$. They can be cleanly converted by chlorination into trichloromethyl aryl ethers [17]. This step is then followed by fluorination using antimony trifluoride and a catalytic amount of antimony pentachloride (Scheme 3 ). The latter compounds can be obtained directly when treated with molybdenum hexafluoride [22]. Unfortunately, the high percutaneous toxicity of the chlorothionoformates $\mathbf{1}$ prohibited any industrial exploitation so far.

W. Sheppard described in 1964 the syntheses of aryl trifluoromethylethers [23] by reaction of $\mathrm{SF}_{4}$ with aryl fluoroformates. However, this approach implied the use of highly toxic reagents and the fluoroformates were rarely isolated (Scheme 4 and Table 4).

\section{Fluorodesulfurization methods}

Recently, an elegant method towards trifluoromethyl ethers based on an oxidative desulfurization-fluorination has been disclosed by Hiyama [24-27]. When dithiocarbonates (2, xanthogenates) are exposed to a huge excess of hydrogen fluoride-pyridine and 1,3-dibromo-5,5-dimethylhydantoin, trifluoromethyl ethers form in moderate to excellent yields (Scheme 5 and Table 5).

What makes this procedure attractive is its applicability to the conversion of aliphatic alcohols into trifluoromethyl alkyl

Scheme 2: Preparation of trifluoromethyl ethers via an in situ chlorination/fluorination sequence.

Table 3: Synthesis of $\mathrm{ArOCF}_{3}$ compounds via an in situ $\mathrm{Cl} / \mathrm{F}$ exchange.

\begin{tabular}{|c|c|c|c|c|c|}
\hline Phenol (mol) & $\mathrm{CCl}_{4}(\mathrm{~mol})$ & $\mathrm{HF}(\mathrm{g})$ & Conditions & $\mathrm{ArOCF}_{3}$ & Yield (\%) \\
\hline $\mathrm{C}_{6} \mathrm{H}_{5} \mathrm{OH}$ & & & $100^{\circ} \mathrm{C} / 2 \mathrm{~h}$ & $\mathrm{C}_{6} \mathrm{H}_{5} \mathrm{OCF}_{3}$ & 10 \\
\hline$(0.05)$ & 0.15 & 30 & $150{ }^{\circ} \mathrm{C} / 4 \mathrm{~h}$ & & \\
\hline $4-\mathrm{O}_{2} \mathrm{NC}_{6} \mathrm{H}_{4} \mathrm{OH}$ & & & $150{ }^{\circ} \mathrm{C} / 8 \mathrm{~h}$ & $4-\mathrm{O}_{2} \mathrm{NC}_{6} \mathrm{H}_{4} \mathrm{OCF}_{3}$ & 56 \\
\hline$(0.15)$ & 0.15 & 40 & & & \\
\hline $4-\mathrm{O}_{2} \mathrm{NC}_{6} \mathrm{H}_{4} \mathrm{OH}$ & & & $100^{\circ} \mathrm{C} / 8 \mathrm{~h}$ & $4-\mathrm{O}_{2} \mathrm{NC}_{6} \mathrm{H}_{4} \mathrm{OCF}_{2} \mathrm{Cl}$ & 45 \\
\hline$(0.06)$ & 0.15 & 40 & & & \\
\hline $4-\mathrm{ClC}_{6} \mathrm{H}_{4} \mathrm{OH}$ & & & $150{ }^{\circ} \mathrm{C} / 8 \mathrm{~h}$ & $2-\mathrm{ClC}_{6} \mathrm{H}_{4} \mathrm{OCF}_{3}$ & 70 \\
\hline$(0.6)$ & 1.8 & 400 & & & \\
\hline $3-\mathrm{H}_{2} \mathrm{NC}_{6} \mathrm{H}_{4} \mathrm{OH}$ & & & $140{ }^{\circ} \mathrm{C} / 8 \mathrm{~h}$ & $3-\mathrm{H}_{2} \mathrm{NC}_{6} \mathrm{H}_{4} \mathrm{OCF}_{3}$ & 26 \\
\hline$(0.6)$ & 1.8 & 400 & & & \\
\hline $2-\mathrm{FC}_{6} \mathrm{H}_{3} \mathrm{OH}$ & & & $150{ }^{\circ} \mathrm{C} / 8 \mathrm{~h}$ & $2-\mathrm{FC}_{6} \mathrm{H}_{3} \mathrm{OCF}_{3}$ & 35 \\
\hline$(0.07)$ & 0.21 & 40 & & & \\
\hline $4-\mathrm{MeC}_{6} \mathrm{H}_{4} \mathrm{OH}$ & & & $100{ }^{\circ} \mathrm{C} / 2 \mathrm{~h}$ & $4-\mathrm{MeC}_{6} \mathrm{H}_{4} \mathrm{OCF}_{3}$ & 20 \\
\hline$(0.05)$ & 0.12 & 30 & $150{ }^{\circ} \mathrm{C} / 4 \mathrm{~h}$ & & \\
\hline
\end{tabular}

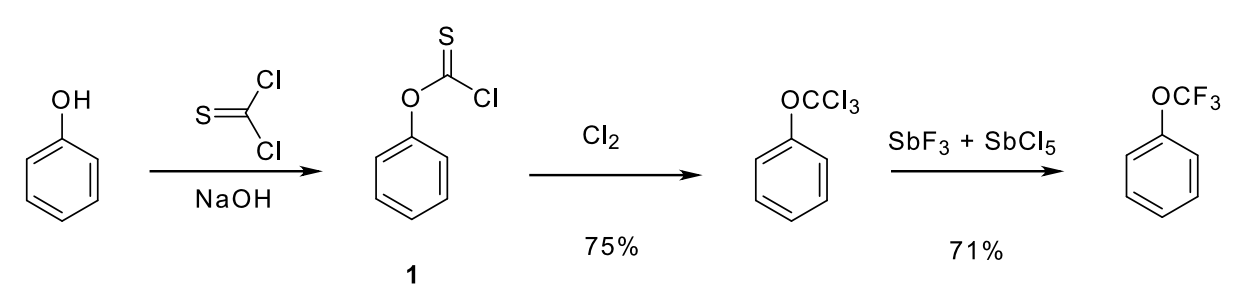

Scheme 3: Preparation of trifluoromethyl ethers via chlorothionoformates. 
<smiles>[R]c1ccc(O)cc1</smiles><smiles>[R]c1ccc(OC(=O)F)cc1</smiles><smiles>[R]c1ccc(OC(F)(F)F)cc1</smiles>

Scheme 4: Preparation of trifluoromethyl ethers via fluoroformates.

Table 4: Preparation of aryl trifluoromethyl ethers by two-step method from phenols ${ }^{a}$.

\begin{tabular}{|c|c|c|c|c|}
\hline Phenol (mol) & $\mathrm{COF}_{2}(\mathrm{~mol})$ & $\mathrm{SF}_{4}(\mathrm{~mol})$ & $\mathrm{ArOCF}_{3}$ & Yield (\%) \\
\hline $\mathrm{C}_{6} \mathrm{H}_{5} \mathrm{OH}$ & & & $\mathrm{C}_{6} \mathrm{H}_{5} \mathrm{OCF}_{3}$ & 62 \\
\hline (2.5) & 3.0 & 2.5 & & \\
\hline $4-\mathrm{O}_{2} \mathrm{NC}_{6} \mathrm{H}_{4} \mathrm{OH}$ & & & $4-\mathrm{O}_{2} \mathrm{NC}_{6} \mathrm{H}_{4} \mathrm{OCF}_{3}$ & 81 \\
\hline$(1.0)$ & 1.5 & 1.5 & & \\
\hline $4-\mathrm{ClC}_{6} \mathrm{H}_{4} \mathrm{OH}$ & & & $2-\mathrm{ClC}_{6} \mathrm{H}_{4} \mathrm{OCF}_{3}$ & 58 \\
\hline$(0.25)$ & 0.38 & 0.28 & & \\
\hline $2-\mathrm{ClC}_{6} \mathrm{H}_{4} \mathrm{OH}$ & & & $2-\mathrm{ClC}_{6} \mathrm{H}_{4} \mathrm{OCF}_{3}$ & 17 \\
\hline$(0.25)$ & 0.38 & 0.28 & & \\
\hline $4-\mathrm{FC}_{6} \mathrm{H}_{4} \mathrm{OH}$ & & & $4-\mathrm{FC}_{6} \mathrm{H}_{4} \mathrm{OCF}_{3}$ & 42 \\
\hline$(0.13)$ & 0.22 & 0.16 & & \\
\hline 4- $\mathrm{MeC}_{6} \mathrm{H}_{4} \mathrm{OH}$ & & & $4-\mathrm{MeC}_{6} \mathrm{H}_{4} \mathrm{OCF}_{3}$ & 9 \\
\hline$(1.0)$ & 1.35 & 1.2 & & \\
\hline
\end{tabular}

${ }^{a}$ Reactions run in "Haselloy-lined" pressure vessel of 140,240 , or $1000 \mathrm{~mL}$. capacity at autogenous pressure. Normal heating pattern was $1 \mathrm{~h}$ at 100 ${ }^{\circ} \mathrm{C}$ followed by 2 to $3 \mathrm{~h}$ at $140{ }^{\circ} \mathrm{C}$ (or higher temperatures above phenol melting point) for the $\mathrm{COF}_{2}$ reaction; $2 \mathrm{~h}$ successively at 100,140 , or $150{ }^{\circ} \mathrm{C}$, and 160 or $175^{\circ} \mathrm{C}$ for the $\mathrm{SF}_{4}$ reaction.

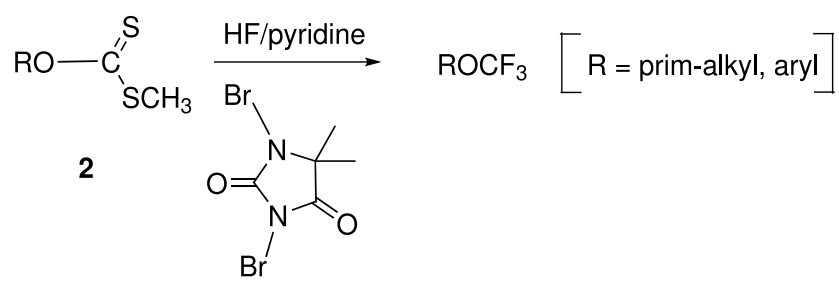

Scheme 5: Oxidative desulfurization-fluorination toward trifluoromethyl ethers.

Table 5: Oxidative desulfurization-fluorination towards $\mathrm{ROCF}_{3}$ compounds.

\begin{tabular}{|c|c|c|c|c|}
\hline Xanthogenate 2 & Fluoride source ${ }^{a}(\mathrm{~mol})$ & $N$-halo imide ${ }^{b}(\mathrm{~mol})$ & $\operatorname{ArOCF}_{3}{ }^{c}$ & Yield (\%) \\
\hline \multirow[t]{2}{*}{ 4-n-Pr- $\mathrm{C}_{6} \mathrm{H}_{4}-$} & $70 \%$ HF/Py (40) & $\mathrm{DBH}(3)$ & $4-n-\mathrm{Pr}-\mathrm{C}_{6} \mathrm{H}_{4}-\mathrm{OCF}_{3}$ & 81 \\
\hline & $\mathrm{TBAH}_{2} \mathrm{~F}_{3}(5)$ & NBS (4) & 4-n-Pr- $\mathrm{C}_{6} \mathrm{H}_{4}-\mathrm{OCF}_{2} \mathrm{SMe}$ & 58 \\
\hline 4-n-Hex- $\mathrm{C}_{6} \mathrm{H}_{4-}$ & $70 \% \mathrm{HF} / \mathrm{Py}(80)$ & $\mathrm{DBH}(3)$ & $4-n-\mathrm{Hex}-\mathrm{C}_{6} \mathrm{H}_{4}-\mathrm{OCF}_{3}$ & 50 \\
\hline $4-\mathrm{PhCH}_{2} \mathrm{O}-\mathrm{C}_{6} \mathrm{H}_{4}^{-}$ & $70 \%$ HF/Py (80) & $\mathrm{DBH}(4)$ & $4-\mathrm{PhCH}_{2} \mathrm{O}-\mathrm{C}_{6} \mathrm{H}_{4}-\mathrm{OCF}_{3}$ & 56 \\
\hline $4-\mathrm{Br}-\mathrm{C}_{6} \mathrm{H}_{4-}^{-}$ & $70 \%$ HF/Py (80) & $\mathrm{DBH}(3)$ & $4-\mathrm{Br}-\mathrm{C}_{6} \mathrm{H}_{4}-\mathrm{OCF}_{3}$ & 62 \\
\hline $\mathrm{Ph}-\mathrm{CH}_{2} \mathrm{CH}_{2} \mathrm{CH}_{2^{-}}$ & 70\% HF/Py (80) & $\mathrm{DBH}(3)$ & $\mathrm{Ph}-\mathrm{CH}_{2} \mathrm{CH}_{2} \mathrm{CH}_{2}-\mathrm{OCF}_{3}$ & 75 \\
\hline$n-\mathrm{C}_{16} \mathrm{H}_{33^{-}}$ & 70\% HF/Py (80) & DBH (3) & $n-\mathrm{C}_{16} \mathrm{H}_{33}-\mathrm{OCF}_{3}$ & 95 \\
\hline
\end{tabular}

${ }^{a} \mathrm{Mol}$ amounts of HF/Py $(70 \%)$ or tetrabutylammonium dihydrogen trifluoride $\left(\mathrm{TBAH}_{2} \mathrm{~F}_{3}\right)$ for 1 mol of 2. ${ }^{b}$ Mol amounts of 1,3-dibromo-5,5-dimethylhydantoin (DBH) or N-bromosuccinimide (NBS). CIsolated yield. 


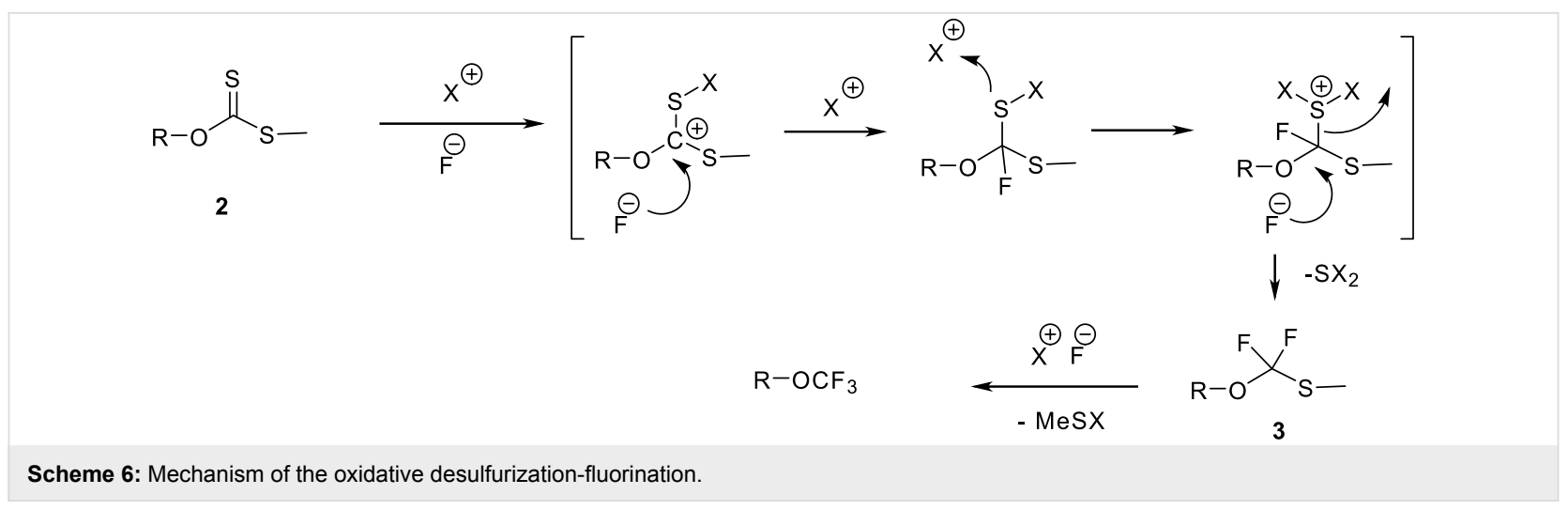

ethers provided that the alcohol is primary rather than benzylic, secondary or tertiary (in which case the reaction fails). The mechanism is based on the nucleophilic attack of the carbonsulfur bond on a positively charged halogen which makes subsequently the nucleophilic substitution by a fluoride possible (Scheme 6). Under modified reaction conditions, for example by using $\mathrm{TBAH}_{2} \mathrm{~F}_{3}$ instead of HF-pyridine, the transient monothioacetals 3 can be isolated [24].

\section{$\mathrm{CF}_{3}$-Transfer agents}

Umemoto reported recently in detail on the preparation of $O$-(trifluoromethyl)dibenzofuranium salts 4 [28-31] and their use as $\mathrm{CF}_{3}$-transfer agents based on studies of Yagupol'skii [32]. The direct $O$ - and $N$-trifluoromethylation of alcohols, phenols, amines, anilines and pyridines under mild conditions was described. However, the difficulty in the use of these reagents is the in situ preparation by photochemical decomposition of the corresponding 2-(trifluoromethoxy)biphenylyl-2'diazonium salts at $-100{ }^{\circ} \mathrm{C}$ (Scheme 7) [28]. The major draw- back of this method is the necessity to work at very low temperature and on small scale.

Togni managed very recently to circumvent these difficulties by using hypervalent iodine compounds such as $\mathbf{5}$ [33-35]. When 2,4,6-trimethylphenol was treated with the hypervalent iodine compound depicted below, the corresponding trifluoromethyl ether was obtained beside C-trifluoromethylation products (Scheme 8).

Alkyl trifluoromethyl ethers, still a rarity, have so far been prepared by the reaction of alkyl fluoroformates with sulfur tetrafluoride [36], the trifluoromethyl transfer from $O$-(trifluoromethyl)dibenzofuranium hexafluoroantimonate 4 [37] and the addition of trifluoromethyl hypofluorite $\left(\mathrm{FOCF}_{3}\right)$ to olefins [38].

The introduction of the trifluoromethoxy substituent into carbohydrates was realized using tris(dimethylamino)sulfonium

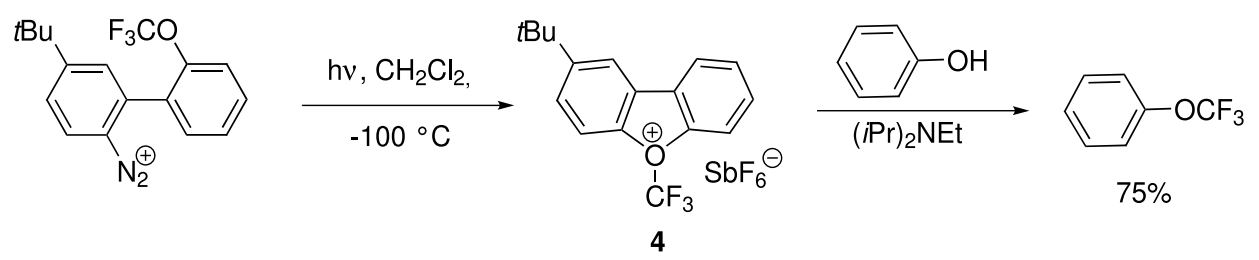

Scheme 7: Umemoto's O-(trifluoromethyl)dibenzofuranium salts 4 as $\mathrm{CF}_{3}$-transfer agents.<smiles>Cc1cc(C)c(O)c(C)c1</smiles><smiles>Cc1cc(C)c(OC(F)(F)F)c(C)c1</smiles><smiles>CC1=CC(C)(C(F)(F)F)C(=O)C(C)=C1</smiles><smiles>CC1=CC(C)(C(F)(F)F)C=C(C)C1=O</smiles>

$3: 2: 5$ 


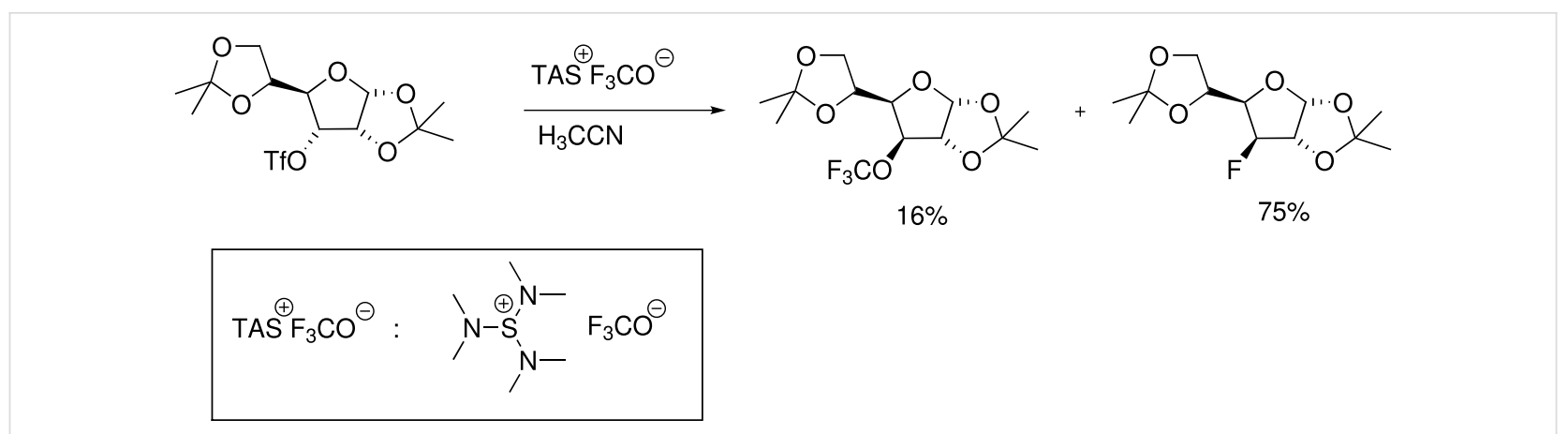

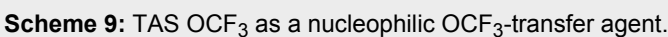

trifluoromethoxide $\left(\mathrm{TASOCF}_{3}\right.$ ) as $\mathrm{OCF}_{3}$-transfer reagent [39]. This compound can be prepared by reaction of carbonyl fluoride with tris(dimethylamino)sulfonium difluorotrimethylsilicate in anhydrous $\mathrm{THF}$ at $-75^{\circ} \mathrm{C}$ (Scheme 9) [40]. The trifluoromethoxide anion is a relatively poor nucleophile. However, when reacted with primary triflate esters of carbohydrates, the anion displaced the triflate under mild conditions.

However, although aromatic trifluoromethyl ethers are well known and have many applications in pharmaceutical and agricultural domains, aliphatic trifluoromethyl ethers are still rare and difficult to make [41]. Methyl (trifluoromethoxy)acetate for example has been prepared [42] using the carbonyl fluoride/ sulfur tetrafluoride method cited above [36]. Recent advances in the fluorodesulfurization reaction [24,41,43-45] enabled the preparation of some aliphatic trifluoromethyl ethers under mild conditions.

\section{Properties}

What makes the introduction of $\mathrm{OCF}_{3}$ into pharmaceutically relevant compounds particularly intriguing is their unique electron distribution. The geminal combination of an alkoxy or aryloxy group with a fluorine atom offers the possibility of bonding/non-bonding resonance which can be formally expressed by the superposition of a covalent and an ionic limiting structure (Figure 2).

Figure 2: Mesomeric structures of the $\mathrm{OCF}_{3}$-group.

\section{Structure}

The anomeric effect reveals itself by a lengthening of the acceptor bond and a shortening of the donor bond. The differences are nevertheless small at least as far as the carbonfluorine bond is concerned which in general is elongated by just
$0.02 \AA$. In contrast, anomerically active carbon-oxygen bonds may shrink by almost $0.1 \AA$. The stable tris(dimethylamino) sulfonium (TAS) trifluoromethoxide (see Scheme 9 for structure) [40] represents an extreme case. The three carbon-fluorine bonds are stretched by approximately $0.07 \AA$ and the carbonoxygen bond contracted by $0.09 \AA$ relative to trifluoromethanol [40] and by $0.21 \AA$ relative to methanol [46].

The geminally 1,1-difluorinated 2,3,4,6-tetra- $O$-acetyl-1-deoxyD-glucopyranose (6, Figure 3) [47] exhibits unequivocally nonidentical C-F bond lengths, according to crystallography. The difference of 1.5 hundredth of an $\AA$ falls in the expected range.
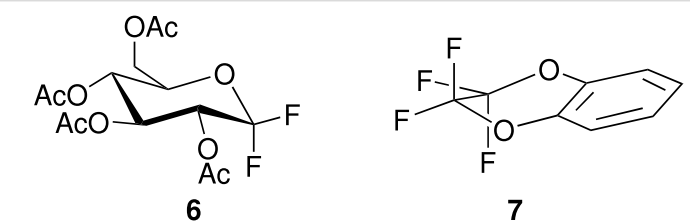

Figure 3: Structures of 6 and 7.

2,2,3,3-Tetrafluoro-2,3-dihydro-1,4-benzodioxine (7, Figure 3) which occupies a half-chair conformation, shows clearly differences between quasi-axial and quasi-equatorial fluorine atoms. The average bond lengths of 1.355 and $1.330 \AA$ differ significantly [48].

The effect of replacing a methyl by a trifluoromethyl moiety on bond length is dependent upon the electronegativity of the atom to which the substituent is attached [49] and reflects the "anomeric effect" shown above [50]. The lengthening of the acceptor bond and the shortening of the donor bond are small, as far as the carbon fluorine bond are concerned. However the carbon-oxygen bond may decrease by almost one tenth of an $\AA$ (Table 6).

A fluorine substituent can lead to a change in the preferred molecular conformation. For example, methoxybenzenes 


\begin{tabular}{|c|c|c|c|c|}
\hline \multirow[t]{2}{*}{ Atom/group $\mathrm{Y}-\mathrm{CX}_{3}(\mathrm{X}=\mathrm{H}, \mathrm{F})$} & \multirow[t]{2}{*}{ Allred-Rochow Electronegativity } & \multicolumn{2}{|c|}{ C-Y bond length in $\AA$} & \multirow[t]{2}{*}{$\Delta r=r\left(C F_{3}\right)-r\left(C H_{3}\right)$ in $\AA$} \\
\hline & & $X=H$ & $X=F$ & \\
\hline$P-\left(C X_{3}\right)$ & 2.06 & 1.844 & 1.904 & +0.060 \\
\hline $\mathrm{H}-\left(\mathrm{CX}_{3}\right)$ & 2.20 & 1.099 & 1.102 & +0.003 \\
\hline $\mathrm{I}-\left(\mathrm{CX}_{3}\right)$ & 2.21 & 2.139 & 2.138 & -0.001 \\
\hline $\mathrm{S}-\left(\mathrm{CX}_{3}\right)$ & 2.44 & 1.805 & 1.819 & +0.014 \\
\hline $\mathrm{Se}-\left(\mathrm{CX}_{3}\right)$ & 2.48 & 1.945 & 1.980 & +0.035 \\
\hline $\mathrm{Br}-\left(\mathrm{CX}_{3}\right)$ & 2.74 & 1.939 & 1.923 & -0.016 \\
\hline $\mathrm{Cl}-\left(\mathrm{CX}_{3}\right)$ & 2.83 & 1.781 & 1.752 & -0.029 \\
\hline $\mathrm{N}-\left(\mathrm{CX}_{3}\right)$ & 3.07 & 1.458 & 1.426 & -0.032 \\
\hline $\mathrm{O}-\left(\mathrm{CX}_{3}\right)$ & 3.50 & 1.416 & 1.369 & -0.047 \\
\hline $\mathrm{F}-\left(\mathrm{CX}_{3}\right)$ & 4.10 & 1.385 & 1.319 & -0.066 \\
\hline
\end{tabular}

without ortho substituents favor a planar conformation. However, Roche researchers by searching trifluoromethoxybenzenes without ortho substituents in the Cambridge Structural Database, found that none of the entries has the $-\mathrm{OCF}_{3}$ group in the plane of the phenyl ring (Figure 4). From six compounds, five entries have a dihedral angle C-C-O-C of around $90^{\circ}$ and one compound showed a skew conformation (dihedral angle $\left.\mathrm{C}=\mathrm{C} / \mathrm{OCF}_{3}: 36^{\circ}\right)[51]$.

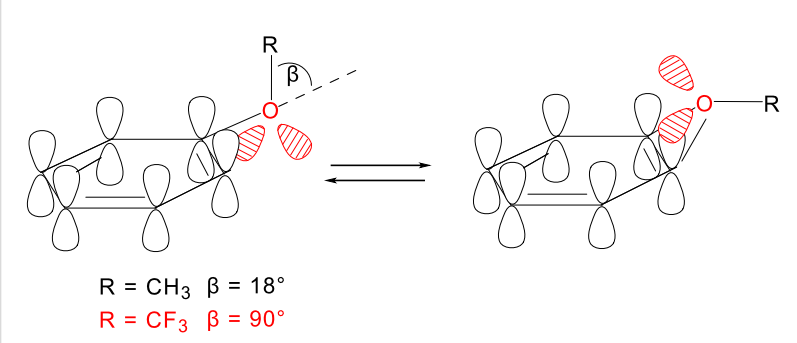

Figure 4: Conformational preference of the trifluoromethoxy group on aryl rings.

\section{Lipophilicity}

On the basis of its electronic properties, which are close to those of a chlorine or a fluorine atom [52], the trifluoromethoxy group has been referred to as a super- [53] or a pseudo-halogen [54]. The advantage of incorporating a trifluoromethoxy group into a molecule can be described in terms of its properties. The trifluoromethoxy group is both more electron withdrawing and lipophilic than its methoxy analogue.

The fluorinated carbon adjacent to an oxygen atom increases lipophilicity as shown by the high value of the $\mathrm{OCF}_{3}$ hydrophobic substituent parameter. While both trifluoromethyl and trifluoromethoxy substituents invariably boost the lipophilicity (Table 7), single fluorine atoms may alter this parameter in either direction. If the halogen occupies a vicinal or homovi- cinal position with respect to a hydroxy, alkoxy or carbonyl oxygen atom, it enhances the solvation energy in water more than in organic solvents (such as 1-octanol or chloroform) and hence lowers the lipophilicity [51]. It appears that the $\mathrm{OCF}_{3}$ substituent is far more lipophilic $(\pi=+1.04)$ than the halogens and lies between a $\mathrm{CF}_{3}(\pi=+0.88)$ and a $\mathrm{SCF}_{3}(\pi=+1.44)$ group. It may thus replace advantageously a fluorine atom $(\pi=$ +0.14 ) in most molecules with the benefit of increased lipid solubility.

\begin{tabular}{|c|c|c|}
\hline Atom/group & $\begin{array}{l}\text { Pauling } \\
\text { Electronegativity }\end{array}$ & $\begin{array}{l}\text { Hydrophobicity } \\
\pi[55,56]\end{array}$ \\
\hline $\mathrm{H}$ & 2.1 & 0.00 \\
\hline $\mathrm{F}$ & 4.0 & 0.14 \\
\hline $\mathrm{Cl}$ & 3.0 & 0.71 \\
\hline $\mathrm{Br}$ & 2.8 & 0.86 \\
\hline I & 2.5 & 1.12 \\
\hline $\mathrm{CH}_{3}$ & 2.3 & 0.56 \\
\hline $\mathrm{C}\left(\mathrm{CH}_{3}\right)_{3}$ & 2.3 & 1.98 \\
\hline $\mathrm{CF}_{3}$ & 3.5 & 0.88 \\
\hline $\mathrm{OCH}_{3}$ & 2.7 & -0.02 \\
\hline $\mathrm{OCF}_{3}$ & 3.7 & 1.04 \\
\hline $\mathrm{SCF}_{3}$ & - & 1.44 \\
\hline $\mathrm{C}_{6} \mathrm{H}_{5}$ & - & 1.96 \\
\hline $\mathrm{SF}_{5}$ & - & 1.23 \\
\hline
\end{tabular}

\section{Acidity of trifluoromethyl ethers}

As described previously, the trifluoromethoxy group is at the same time a strong electron-withdrawing substituent due to the three fluorine atoms and a $\pi$-donating substituent due to the oxygen lone pairs. Yagupol'skii [57,58] and Sheppard [53,59] provided detailed data on the $\mathrm{p} K_{\mathrm{a}}$-values of benzoic acids and phenols which reveal that the trifluoromethoxy group is a moderately electron-withdrawing moiety which resembles a 
<smiles>COc1ccccc1</smiles><smiles>COc1ccccc1[N+](=O)[O-]</smiles><smiles>O=[N+]([O-])c1ccc(O)cc1</smiles><smiles>O=[AsH2]O[Na]</smiles>
$1: 1.3$<smiles>O=[N+]([O-])c1ccccc1OC(F)F</smiles><smiles>O=[N+]([O-])c1ccc(OC(F)F)cc1</smiles><smiles>O=S(=O)(O)O[Na]</smiles><smiles>O=[N+]([O-])c1ccc(OC(F)F)c([N+](=O)[O-])c1</smiles>

$1: 2.6$<smiles>O=[N+]([O-])c1ccccc1OC(F)(F)F</smiles><smiles>O=[N+]([O-])c1ccc(OC(F)(F)F)cc1</smiles><smiles>COc1cc([N+](=O)[O-])cc([N+](=O)[O-])c1</smiles>

$50 \%$

Scheme 10: Nitration of trifluoromethoxy benzene.

chlorine atom. The $\mathrm{p} K_{\mathrm{a}}$ values are lowered by the trifluoromethoxy group by $0.5-1.0$ units [60-62].

\section{Reactivity}

The $\mathrm{OCF}_{3}$ group is thermally and chemically resistant to attack by acids, bases, organometallic reagents and oxidizing/reducing agents $[23,36]$. When substituted on an aromatic ring, the trifluoromethoxy group exhibits similar electron withdrawing behavior to the alkoxy group but also acts to deactivate the aromatic ring system [53].

\section{Electrophilic Aromatic Substitution}

Trifluoromethoxybenzene, for example, undergoes nitration considerably (up to 5 times) more slowly than benzene. The electrophilic substitution occurs selectively at the ortho and para position. This means the inductive electron-withdrawing effect compromises the attack of the electrophile, but is counterbalanced, to some extent, by the capacity of the ether oxygen to act through resonance as an electron donor. This antagonistic behavior is well known for chloro and bromo substituents. The trifluoromethoxy substituent has a pronounced preference for the para substitution. Unless the para position is occupied, ortho isomers are formed only in small amounts $(\leq 10 \%)$ without any trace amounts of the meta isomers [52,63,64].

When nitration is carried out under standard conditions, the ortho/para ratio changes with the number of fluorine atoms as depicted in Scheme $10[52,65,66]$. At temperatures in the range of $25-50{ }^{\circ} \mathrm{C}$, double nitration can be achieved. The resulting 2,4-dinitrophenyl ethers are isolated in moderate to excellent yield $[29,66,67]$.

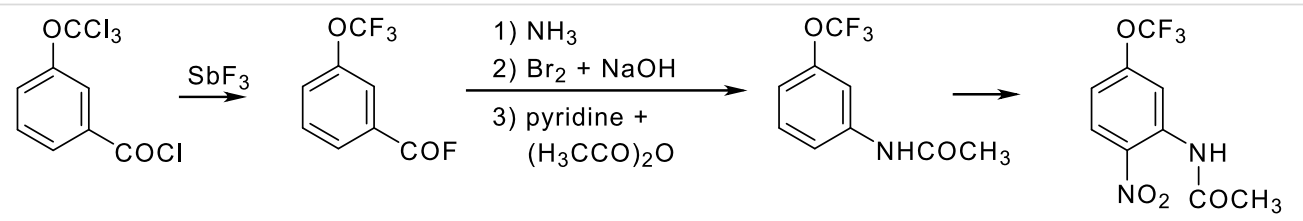

$20 \%$<smiles>O=C(Cl)c1ccc(OC(Cl)(Cl)Cl)cc1</smiles><smiles>C[SeH2-]</smiles><smiles>FC(F)(F)Oc1ccc(C(F)(F)F)cc1</smiles><smiles>CC(=O)Nc1ccc(OC(F)(F)F)cc1</smiles><smiles>CC(=O)Nc1ccc(OC(F)(F)F)c([N+](=O)[O-])c1</smiles> 
The para-directing effect of a trifluoromethoxy group surpasses even that of an amide function. $\mathrm{N}$-Acetyl-3-(trifluoromethoxy) aniline is nitrated mainly at the 6-position and to a minor extent $(10 \%)$ at the 4-position (Scheme 11) [19]. N-Acetyl-4(trifluoromethoxy)aniline reacts at the 3-position (again meta with respect to the nitrogen function and ortho to the trifluoromethoxy group!).

The pronounced preference for para substitution of (trifluoromethoxy)benzene $[52,63,64]$ holds for most electrophilic aromatic substitutions, in particular sulfonation [64], bromination [52], chloromethylation [68] and acylation [52,64]. Attack at the meta position has so far been observed only with the isopropylation and ethylation of (trifluoromethoxy)benzene (to the extent of 9 and $31 \%$, respectively) [52].

\section{Organometallic Reactions}

Some very versatile methodology functionalizing trifluoromethoxy substituted aromatics is based on the synthesisoriented organometallic chemistry. The metal is introduced into a substrate in general by either one of two favorite methods, the permutational interconversion of halogen against metal or hydrogen against metal and subsequently replaced by an electrophile $[69,70]$.

The three isomeric bromo(trifluoromethoxy)benzenes react easily with butyllithium in diethyl ether at $-75^{\circ} \mathrm{C}$ to generate the corresponding aryllithium (Scheme 12) species which can be trapped by a variety of electrophiles furnishing a diversity of new products (Table 8) [71,72].

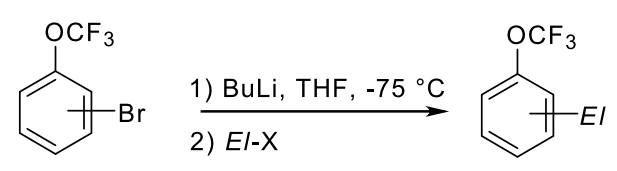

Scheme 12: Bromine/lithium exchange of bromo(trifluoromethoxy) benzenes.
Table 8: Reaction of 2-, 3- and 4-(trifluoromethoxy)phenyllithiums and electrophiles.

\begin{tabular}{llll} 
& \\
\hline $\mathrm{B}(\mathrm{OH})_{2}$ & $89 \%$ & $72 \%$ & $84 \%$ \\
$\mathrm{OH}$ & $88 \%$ & & \\
$\mathrm{Br}$ & $71 \%$ & $74 \%$ & $86 \%$ \\
$\mathrm{I}$ & $81 \%$ & $77 \%$ & $73 \%$ \\
$\mathrm{CH}$ & $52 \%$ & $78 \%$ & $70 \%$ \\
$\mathrm{CH}$ & \\
$\mathrm{CHO}$ & $<5 \%$ & $90 \%$ & $95 \%$ \\
$\mathrm{COCH}$ & $93 \%$ & $63 \%$ & $61 \%$ \\
$\mathrm{COCH} \mathrm{COCC}_{2} \mathrm{H}_{5}$ & $52 \%$ & $32 \%$ & $26 \%$ \\
$\mathrm{COOH}$ & $80 \%$ & $85 \%$ & $95 \%$ \\
$\mathrm{CN}$ & $49 \%$ & & $21 \%$ \\
& $87 \%$ &
\end{tabular}

Trifluoromethoxybenzene reacts with sec-butyllithium in the presence of $N, N, N^{\prime}, N^{\prime}$-tetramethylethylenediamine ("TMEDA") smoothly under hydrogen/metal permutation ("metalation") as shown in Scheme 13 [72].

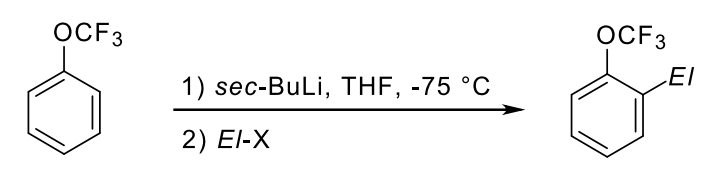

Scheme 13: Metalation of (trifluoromethoxy)benzene.

4-Trifluoromethoxybiphenyl can be metalated using the Schlosser superbase LIC-KOR made by combining butyllithium (LIC) with potassium tert-butoxide (KOR) in tetrahydrofuran at $-100{ }^{\circ} \mathrm{C}$. Upon trapping with molecular iodine, 3 -iodo-4-trifluoromethoxybiphenyl was isolated in $90 \%$ yield [73]. Under the same conditions as employed with trifluoromethoxybenzene, 1- and 2-trifluoromethoxynaphthalene

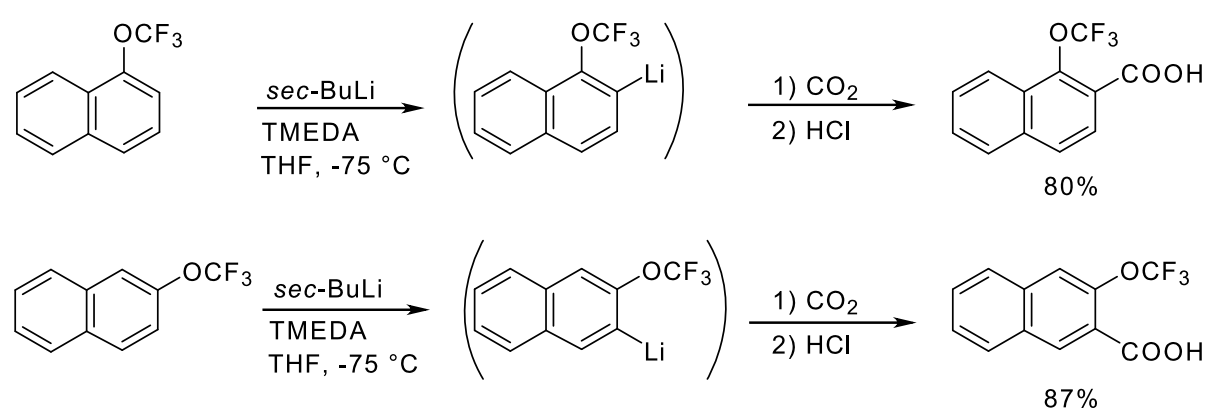


undergo selective lithiation at the 2- and 3-position, respectively (Scheme 14) [74].

Both the trifluoromethyl and the trifluoromethoxy group are strongly electron-withdrawing groups and both have a farreaching activating effect [74]. In an intramolecular competition on 1-trifluoromethoxy-4-(trifluoromethyl)benzene it has been shown, that lithiation next to the $\mathrm{OCF}_{3}$ substituent is favoured, probably due to steric reasons. In fact, 1-trifluoromethoxy-4-(trifluoromethyl)benzene (Scheme 15) affords 2-trifluoromethoxy-5-(trifluoromethyl)benzoic acid after lithiation and carboxylation [75].

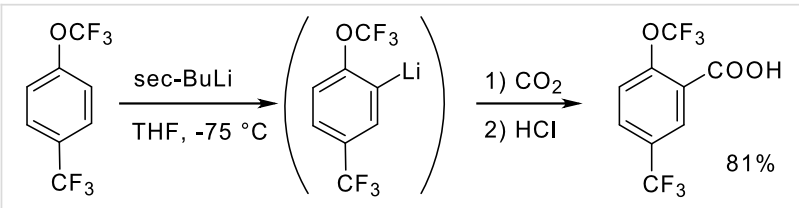

Scheme 15: Competition between $-\mathrm{CF}_{3}$ - and $-\mathrm{OCF}_{3}$ in Metalation reactions.

When the $\mathrm{OCF}_{3}$ substituent is in competition with fluorine, as in fluoro(trifluoromethoxy)benzenes, the fluorine-adjacent positions are always metalated (Scheme 16) [75].

The $\mathrm{OCF}_{3}$ group reveals a powerful $\pi$-polarization as it acidifies not only the ortho but also the meta and para positions strongly. Therefore, metalation of 2- and 4-(trifluoromethoxy) anisole occurs preferentially or exclusively at the methoxyneighboring position. However, proton abstraction at the trifluoromethoxy-adjacent sites becomes dominant when secbutyllithium in the presence of $N, N, N^{\prime}, N^{\prime \prime}, N^{\prime \prime}$-pentamethyl- diethylenetriamine (PMDTA) is employed. 3-Trifluoromethoxyanisole undergoes deprotonation always at the doubly activated 2-position (Scheme 17). The trifluoromethoxy group enhances the kinetic acidity of anisole by a factor of 3 if in the<smiles>COc1cccc(OC(F)(F)F)c1OCC(C)CC(C)C</smiles>

Scheme 17: Metalation of trifluoromethoxyanisoles.<smiles>Fc1cccc(OCCOc2c(F)cccc2Cl)c1F</smiles><smiles>O[C@H](Cl)C(Cl)Cl</smiles><smiles>O=C(O)c1cccc(OC(F)(F)F)c1F</smiles>
$77 \%$<smiles>COc1cccc(F)c1</smiles><smiles>COc1cccc(F)c1[Al]C</smiles><smiles>O=C(O)OCC(=O)C(Cl)Cl</smiles><smiles>O=C(O)c1c(F)cccc1OC(F)(F)F</smiles><smiles>Fc1ccc(OC(F)(F)F)cc1</smiles>

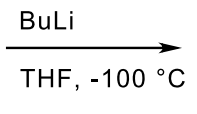<smiles>CCOc1ccc(F)c(CCCC(F)(F)F)c1</smiles>

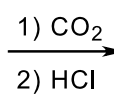<smiles>O=C(O)c1cc(OC(F)(F)F)ccc1F</smiles> 
ortho position, 300 if in the para position and almost 2000 if in the meta position [76].

The long-range effect of the trifluoromethoxy group was rationalized by Schlosser et al. by a synergy between two kinds of electronic perturbations. The electronegativity of nitrogen, oxygen, or a halogen atom pulls electrons in all $\sigma$-bonds towards the heteroelement. This $\sigma$-polarization diminishes with the distance. On the other hand, the substituent affects the $\pi$-electron cloud by attracting the whole sextet as one toward itself if it is both tetravalent and electrondeficient, e.g. trifluoromethyl or trimethylammonio groups. Alternatively, the $\pi$-cloud will remain, as in chlorobenzene, or even be pushed away from
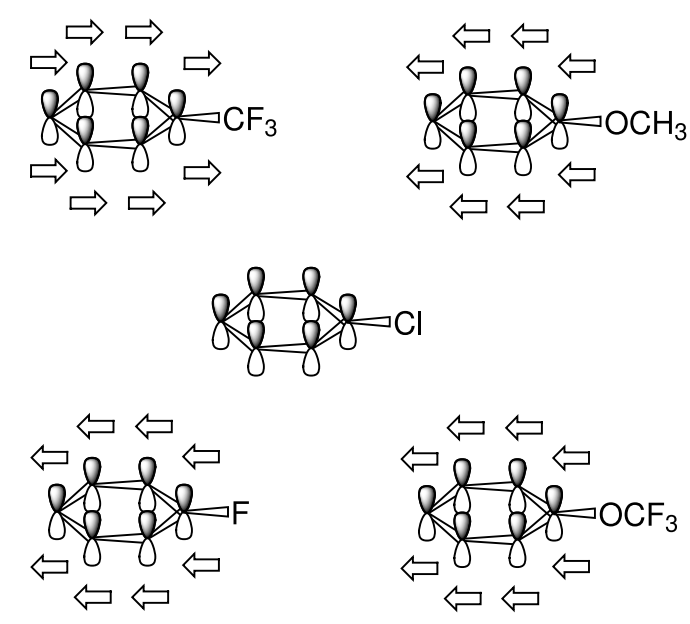

Figure 5: Direction of m-polarization depending on the substituent as described by Schlosser et al. [57]. lone-pair carrying substituents (with progressively increasing strength from fluorine to alkoxy to dialkylamino). In this way, $\pi$-electron density can accumulate at the meta and para positions, where it counterbalances the $\sigma$-polarization. The trifluoromethoxy group has a slightly smaller $\sigma$-inductive effect than fluorine or a trifluoromethyl substituent. Its $\pi$-donating capacity is inferior to the one of the methoxy group, and even inferior to that of a fluorine atom. As a result, these two effects confer its electronic individuality to the trifluoromethoxy group. While acidifying ortho-positions only moderately, its anionstabilizing effect is important at meta- and para-positions (Figure 5) [76].

By contrast, bromo(trifluoromethoxy)benzenes are metalated at $-100{ }^{\circ} \mathrm{C}$ by bases such as LDA at a position next to the oxygen substituent (Scheme 18) [74].

At temperatures above $-75{ }^{\circ} \mathrm{C}$, lithium bromide elimination generates didehydro(trifluoromethoxy)benzenes ("arynes"). These short-lived species can be trapped with furan to form the corresponding Diels-Alder cycloadducts (Scheme 19) [74].

Trifluoromethoxy substituted anilines require protection of the amino function. The BOC-protected ortho and para isomer gives the 3- and 4-(trifluoromethoxy)anthranilic acid after metalation with tert-butyllithium, followed by carboxylation (Scheme 20) [71]. When the amino function is protected instead of a BOC group by a silyl group, 3-trifluoromethoxy- $N$ (trimethylsilyl)aniline is metalated in position 2. However, 3and 4-trifluoromethoxy- $N, N$-bis(trimethylsilyl)aniline are metalated at the oxygen-adjacent position [71].

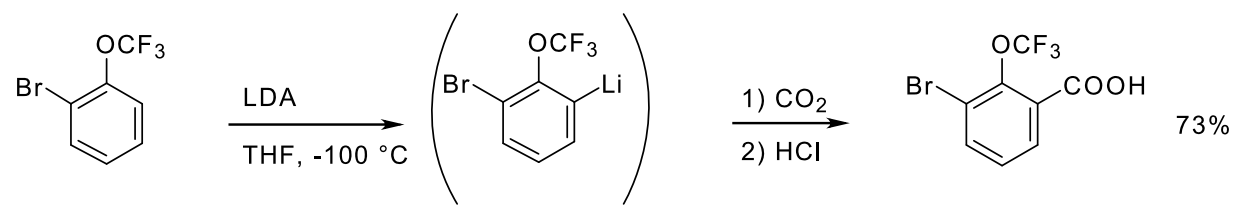

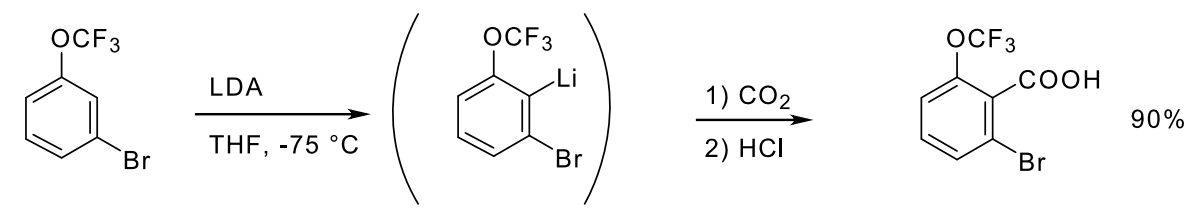

$$
\begin{aligned}
& \underset{\mathrm{Br},-100^{\circ} \mathrm{C}}{\stackrel{\mathrm{LDA}}{\longrightarrow}}
\end{aligned}
$$



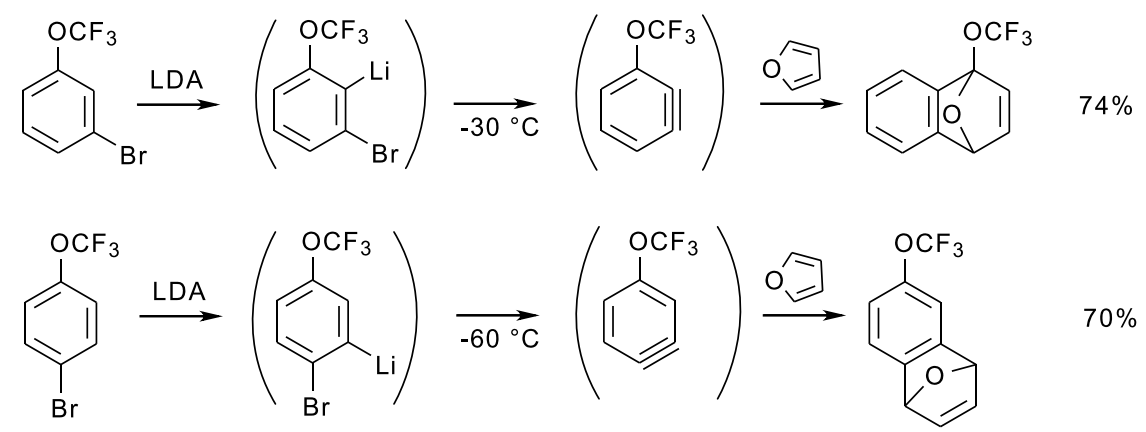

Scheme 19: Aryne formation from bromo(trifluoromethoxy)phenyllithiums and subsequent Diels-Alder cycloaddition with furan.

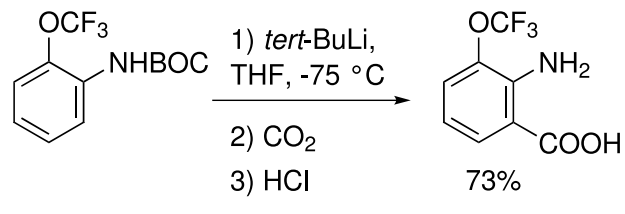

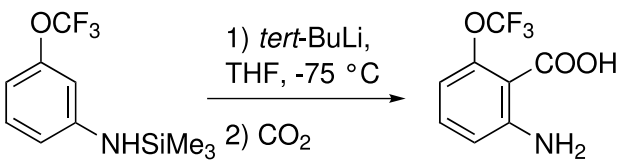

3) $\mathrm{HCl}$<smiles>CC(=O)Oc1ccc(NC(=O)OCc2ccccc2)cc1</smiles>

\section{THF, $-75^{\circ} \mathrm{C}$}

2) $\mathrm{CO}_{2}$

3) $\mathrm{HCl}$
$33 \%$<smiles>Nc1ccc(OC(F)(F)F)cc1C(=O)O</smiles>

$78 \%$

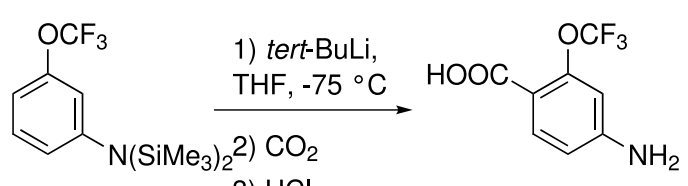

3) $\mathrm{HCl}$

Scheme 20: Metalation of (trifluoromethoxy)anilines.

\section{Conclusion}

In the life science field, single fluorine atoms, trifluoromethyl or trifluoromethoxy groups are used to tailor $\mathrm{p} K_{\mathrm{a}}$ values, to facilitate cell membrane penetration and to increase the metabolic stability of compounds. These features of fluorine contribute to the critical "bioavailability" of therapeutically active compounds. The growing interest and utility of the trifluoromethoxy-substitutent in drugs and agrochemical products, presents challenging synthetic strategies which are increasing being tackled in industrial and academic research programmes.

\section{Acknowledgments}

We thank the Ministère de la Recherche of France and are grateful to the CNRS and Bayer CropScience for a $\mathrm{PhD}$ grant to BM.

\section{References}

1. Thayer, A. M. Chem. Eng. News 2006, 84 (23), 15-24.

2. Tomlin, C. D. S., Ed. The Pesticide Manual, 13th ed.; British Crop Protection Council: Farnham, 2003.

3. Elliott, A. J. In Chemistry of Organic Fluorine Compounds II: A Critical Review; Hudlicky, M.; Pavlath, A. E., Eds.; ACS Monograph 187; American Chemical Society: Washington, DC, 1995; pp 1119-1125.

4. Edwards, P. N. Uses of Fluorine in Chemotherapy. In Organofluorine Chemistry: Principles and Commercial Applications; Banks, R. E.; Smart, B. E.; Tatlow, J. C., Eds.; Plenum Press: New York, 1994.

5. Filler, R.; Kobayashi, Y.; Yagupolskii, L. M., Eds. Organofluorine Compounds in Medicinal Chemistry and Biomedical Applications; Elsevier: Amsterdam, 1993.

6. Filler, R.; Kobayashi, Y., Eds. Biomedicinal Aspects of Fluorine Chemistry; Kodansha Ltd.: Tokyo, 1982.

7. Ojima, I.; McCarthy, J. R.; Welch, J. T., Eds. Biomedical Frontiers of Fluorine Chemistry; ACS Symposium Series 639; American Chemical Society: Washington, DC, 1996.

8. Welch, J. T.; Eswarakrishnan, S. Fluorine in Bioorganic Chemistry; Wiley: New York, 1991. 
9. Banks, R. E.; Smart, B. E.; Tatlow, J. C., Eds. Organofluorine Chemistry: Principles and Commercial Applications; Plenum Press: New York, 1994.

10. Jeschke, P.; Baston, E.; Leroux, F. R. Mini-Rev. Med. Chem. 2007, 7, 1027-1034. doi:10.2174/138955707782110150

11. Jeschke, P. ChemBioChem 2004, 5, 570-589. doi:10.1002/cbic.200300833

12. Leroux, F.; Jeschke, P.; Schlosser, M. Chem. Rev. 2005, 105, 827-856. doi:10.1021/cr040075b

13. Larsen, E. R. Fluorine Chem. Rev. 1969, 3, 1-44.

14. Bagnall, R. D.; Bell, W.; Pearson, K. J. Fluorine Chem. 1977, 9 , 359-375. doi:10.1016/S0022-1139(00)82169-7

15. Franks, N. P.; Lieb, W. R. Nature 1994, 367, 607-614. doi:10.1038/367607a0

16. Yagupol'skii, L. M. Dokl. Akad. Nauk SSSR 1955, 105, 100-102.

17. Yarovenko, N. N.; Vasil'eva, A. S. Zh. Obshch. Khim. 1958, 28 , 2502-2504.

18. Yagupol'skii, L. M.; Orda, V. V. Zh. Obshch. Khim. 1964, 34, 1979-1984.

19. Yagupol'skii, L. M.; Troitskaya, V. I. Zh. Obshch. Khim. 1961, 31, 915-924.

20. Louw, R.; Franken, P. W. Chem. Ind. 1977, 127-128.

21. Feiring, A. E. J. Org. Chem. 1979, 44, 2907-2910. doi:10.1021/jo01330a017

22. Mathey, F.; Bensoam, J. Tetrahedron Lett. 1973, 14, 2253-2256. doi:10.1016/S0040-4039(01)87608-5

23. Sheppard, W. A. J. Org. Chem. 1964, 29, 1-11. doi:10.1021/jo01024a001

24. Kanie, K.; Tanaka, Y.; Suzuki, K.; Kuroboshi, M.; Hiyama, T. Bull. Chem. Soc. Jpn. 2000, 73, 471-484. doi:10.1246/bcsj.73.471

25. Kuroboshi, M.; Kanie, K.; Hiyama, T. Adv. Synth. Catal. 2001, 343, 235-250.

doi:10.1002/1615-4169(20010330)343:3<235::AID-ADSC235>3.0.CO; 2-0

26. Kuroboshi, M.; Suzuki, K.; Hiyama, T. Tetrahedron Lett. 1992, 33, 4173-4176. doi:10.1016/S0040-4039(00)74681-8

27. Shimizu, M.; Hiyama, T. Angew. Chem., Int. Ed. 2005, 44, 214-231. doi:10.1002/anie.200460441

28. Umemoto, T.; Adachi, K.; Ishihara, S. J. Org. Chem. 2007, 72, 6905-6917. doi:10.1021/jo070896r

29. Umemoto, T.; Ishihara, S. Tetrahedron Lett. 1990, 31, 3579-3582. doi:10.1016/S0040-4039(00)94447-2

30. Umemoto, T.; Ishihara, S. J. Am. Chem. Soc. 1993, 115, 2156-2164. doi:10.1021/ja00059a009

31. Umemoto, T.; Adachi, K. J. Org. Chem. 1994, 59, 5692-5699. doi:10.1021/jo00098a030

32. Yagupol'skii, L. M.; Kondratenko, N. V.; Timofeeva, G. N. Zh. Org. Khim. 1984, 20, 115-118.

33. Kieltsch, I.; Eisenberger, P.; Togni, A. Angew. Chem., Int. Ed. 2007, 46, 754-757. doi:10.1002/anie.200603497

34. Eisenberger, P.; Gischig, S.; Togni, A. Chem.-Eur. J. 2006, 12, 2579-2586. doi:10.1002/chem.200501052

35. Stanek, K.; Togni, A. Poster presentation, 15th European Symposium on Fluorine Chemistry, Prague, July 15-20, 2007.

36. Aldrich, P. E.; Sheppard, W. A. J. Org. Chem. 1964, 29, 11-15. doi:10.1021/jo01024a002

37. Umemoto, T. Chem. Rev. 1996, 96, 1757-1777. doi: $10.1021 / \mathrm{cr} 941149 \mathrm{u}$

38. Rozen, S. Chem. Rev. 1996, 96, 1717-1736. doi:10.1021/cr941147+
39. Trainor, G. L. J. Carbohydr. Chem. 1985, 4, 545-563. doi:10.1080/07328308508082676

40. Farnham, W. B.; Smart, B. E.; Middleton, W. J.; Calabrese, J. C.; Dixon, D. A. J. Am. Chem. Soc. 1985, 107, 4565-4567. doi:10.1021/ja00301a043

41. Ben-David, I.; Rechavi, D.; Mishani, E.; Rozen, S. J. Fluorine Chem. 1999, 97, 75-78. doi:10.1016/S0022-1139(99)00031-7

42. Yagupol'skii, L. M.; Alekseenko, A. N.; Il'chenko, A. Y. Ukr. Khim. Zh. (Russ. Ed.) 1978, 44, 1057-1059.

43. Kollonitsch, J.; Marburg, S.; Perkins, L. M. J. Org. Chem. 1976, 41, 3107-3111. doi:10.1021/jo00881a007

44. Sondej, S. C.; Katzenellenbogen, J. A. J. Org. Chem. 1986, 51 , 3508-3513. doi:10.1021/jo00368a022

45. Blazejewski, J.-C.; Anselmi, E.; Wakselman, C. J. Org. Chem. 2001, 66, 1061-1063. doi:10.1021/jo005701t

46. Kimura, K.; Kubo, M. J. Chem. Phys. 1959, 30, 151-158. doi:10.1063/1.1729867

47. Praly, J.-P.; Brard, L.; Descotes, G.; Toupet, L. Tetrahedron 1989, 45, 4141-4152. doi:10.1016/S0040-4020(01)81310-7

48. Praly, J.-P.; Scopelliti, R.; Gorecka, J.; Schlosser, M. . Unpublished results.

49. Oberhammer, H. J. Fluorine Chem. 1983, 23, 147-162. doi:10.1016/S0022-1139(00)84976-3

50. McClinton, M. A.; McClinton, D. A. Tetrahedron 1992, 48, 6555-6666. doi:10.1016/S0040-4020(01)80011-9

51. Böhm, H.-J.; Banner, D.; Bendels, S.; Kansy, M.; Kuhn, B.; Müller, K.; Obst-Sander, U.; Stahl, M. ChemBioChem 2004, 5, 637-643. doi:10.1002/cbic.200301023

52. Olah, G. A.; Yamato, T.; Hashimoto, T.; Shih, J. G.; Trivedi, N.; Singh, B. P.; Piteau, M.; Olah, J. A. J. Am. Chem. Soc. 1987, 109, 3708-3713. doi:10.1021/ja00246a030

53. Sheppard, W. A. J. Am. Chem. Soc. 1963, 85, 1314-1318. doi:10.1021/ja00892a021

54. Haas, A. Adv. Inorg. Chem. Radiochem. 1984, 28, 167-202.

55. Hansch, C.; Leo, A. Substituent Constants for Correlation Analysis in Chemistry and Biology; John Wiley and Sons: New York, 1979.

56. Leo, A.; Jow, P. Y. C.; Silipo, C.; Hansch, C. J. Med. Chem. 1975, 18, 865-868. doi:10.1021/jm00243a001

57. Yagupol'skii, L. M.; Yagupol'skaya, L. N. Dokl. Akad. Nauk SSSR 1960, 134, 1381-1383.

58. Yagupol'skii, L. M.; Bystrov, V. F.; Stepanyants, A. U.; Fialkov, Y. A. Zh. Obshch. Khim. 1964, 34, 3682-3690.

59. Sheppard, W. A. J. Am. Chem. Soc. 1962, 84, 3072-3076. doi:10.1021/ja00875a007

60. Kortüm, G.; Vogel, W.; Andrussow, K. Dissociation Constants of Organic Acids in Aqueous Solution; Butterworths \& Co.: London, 1961.

61. Kortüm, G.; Vogel, W.; Andrussow, K. Pure Appl. Chem. 1961, 1, 187-536.

62. Hansch, C.; Leo, A.; Taft, R. W. Chem. Rev. 1991, 91, 165-195. doi:10.1021/cr00002a004

63. Ansink, H. R. W.; Cerfontain, H. Recl. Trav. Chim. Pays-Bas 1992, 111, 215-221.

64. Desbois, M. Bull. Soc. Chim. Fr. 1986, 885-890.

65. Bunton, C. A.; Minkoff, G. J.; Reed, R. I. J. Chem. Soc. 1947, 1416-1418. doi:10.1039/JR9470001416

66. Shelyazhenko, S. V.; Fialkov, Y. A.; Yagupol'skii, L. M. Zh. Org. Khim. 1992, 28, 1652-1659.

67. Meldola, R.; Woolcott, G. H.; Wray, E. J. Chem. Soc., Trans. 1896, 69, 1321-1334. doi:10.1039/СT8966901321 
68. Fujii, K.; Nakamoto, Y.;Umeyama, H. (Ube Industries, Japan). Jpn. Kokai Tokkyo Koho, filed on December 15, 1999; Chem. Abstr. 2001, 135, 45998.

69. Leroux, F.; Schlosser, M.; Zohar, E.; Marek, I. The Preparation of Organolithium Reagents and Intermediates. In The Chemistry of Organolithium Compounds; Rappoport, Z.; Marek, I., Eds.; John Wiley \& Sons Ltd.: Chichester, 2004; pp 435-493. doi:10.1002/047002111X.ch9

70. Schlosser, M. Angew. Chem., Int. Ed. 2005, 44, 376-393. doi:10.1002/anie.200300645

71. Leroux, F.; Castagnetti, E.; Schlosser, M. J. Org. Chem. 2003, 68, 4693-4699. doi:10.1021/jo0267798

72. Castagnetti, E.; Schlosser, M. Eur. J. Org. Chem. 2001, 691-695. doi:10.1002/1099-0690(200102)2001:4<691::AID-EJOC691>3.0.CO;2A

73. Pauluth, D.; Haas, H. (Merck Patent GmbH, Darmstadt, Germany) Verfahren zur Herstellung von substituiertem Trifluormethoxybenzol. German Patent DE 4219281C1, December 23, 1993.

74. Schlosser, M.; Castagnetti, E. Eur. J. Org. Chem. 2001, 3991-3997. doi:10.1002/1099-0690(200111)2001:21<3991::AID-EJOC3991>3.0.C O;2-J

75. Schlosser, M.; Castagnetti, E.; Cottet, F. Unpublished results. See: Castagnetti, E. Ph.D. Thesis, Université de Lausanne, 2001.

76. Castagnetti, E.; Schlosser, M. Chem.-Eur. J. 2002, 8, 799-804. doi:10.1002/1521-3765(20020215)8:4<799::AID-CHEM799>3.0.CO;26

\section{License and Terms}

This is an Open Access article under the terms of the Creative Commons Attribution License

(http://creativecommons.org/licenses/by/2.0), which permits unrestricted use, distribution, and reproduction in any medium, provided the original work is properly cited.

The license is subject to the Beilstein Journal of Organic Chemistry terms and conditions:

(http://www.beilstein-journals.org/bjoc)

The definitive version of this article is the electronic one which can be found at: doi:10.3762/bjoc. 4.13 